\title{
A Literature Review Child Abuse and Neglect: Potential Impact on Children during a Covid-19 Pandemic
}

\author{
Endang Mei Yunalia, \\ Arif Nurma Etika, \\ Satria Eureka Nurseskasatmata, \\ Wiwin Sulistyawati \\ University of Kadiri, Indonesia \\ Email: \\ endang.mei@unik-kediri.ac.id
}

Keywords: Child abuse, Covid-19, Pandemic.

\begin{abstract}
Staying at home during Covid-19 pandemic is no longer a safety aspect. During lockdown there is clustering of all the family members at home. Parents or caregivers must manage their children's schooling as well as their own work and parenting responsibilities. Some articles mention that Covid-19 pandemic turning into "broader child crisis" such as violence against on children. Child abuse can take place in a home environment under the care of parents or other family members. Analyze the impact of isolation policies caused the spread of COVID-19 and evidence of child abuse during Covid-19 pandemic This literature review is arranged based on literatures studies from 5 databases last 6 years, such as DOAJ, Google Scholar, ResearchGate, SpringerLink, and Elsevier Open Access Journals. This literature review searched for studies with the keyword "child abuse" or "child neglected" or "covid-19 pandemic impact". Based on a search using these keywords, 8 articles were found from the data base.Building awareness about child abuse and neglect during Covid-19 pandemic is vital, because children are often vulnerable and require careful consideration by parents or caregivers and health care system. So, to protecting children from violence during Covid-19 pandemic requires all sectors to undertake coordinate measure (parents or caregiver, school, community and health profession).The health profession has a duty to provide support with public health approach in overcoming about child abuse and neglect.
\end{abstract}

Copyright (C) 2020 IIK STRADA Indonesia All right reserved.

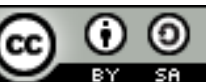

This is an open-acces article distributed under the terms of the Creative Commons Attribution-ShareAlike 4.0 International License.

\section{INTRODUCTION}


Since Desember 2019, an outbreak of coronavirus disease (Covid-19) has spread from Wuhan, China and became a pandemic that getting affect in every country. The Covid-19 outbreak has resulted in the death of nearly 383,000 people worldwide ini June 2020 (Benjamin et al., 2020). Due to the covid 19 pandemic, many individuals feel worried and stressed, where this anxiety and stress can be felt either directly or indirectly. One of the specific psychological problems that occur during a pandemic is that parents are worried about children's education while schools are closed, while on the other hand parents still have to work at home, thus increasing the burden on parents (IASC, 2020).

Many parents will find it stressful to balance work, caring for children, and maintaining the household. For some parents, during lockdown, they lived at home for a long time with their children, especially for families with low incomes, this caused its own problems, especially in terms of child care. There is data showing an increasing level of child abuse and neglect during lockdown (Cluver et al., 2020).

American research shows that parents have higher levels of stress than adults who do not have children. The stress that occurs is caused by worries about finances, education and child care (APA, 2020). Social isolation requires families to remain in their homes resulting in intense and unrelieved contact as well as the depletion of existing support networks, such as through extended family as well as through social or community based support networks for families at risk. Additionally, isolation places children at greater risk of neglect as well as physical, emotional, sexual, and domestic abuse (Gelder, 2020).

A number of studies have tried to detect which children are at higher risk of being abused and neglected. Results indicate risk factors at the level of child and parent characteristics, at the level of family dynamics and at the level of wider community (Đapić, Flander, \& Prijatelj, 2020). Therefore, we investigated and analyzed evidence of child abuse during Covid-19 outbreak and proposed an effective intervention strategy.

Analyze the impact of isolation policies caused the spread of COVID-19 and evidence of child abuse during Covid-19 pandemic

\section{MATERIALS AND METHODS}

The method used in the review literature arranged based on literatures studies from 5 databases last 6 years, such as DOAJ, Google Scholar, ResearchGate, SpringerLink, and Elsevier Open Access Journals. This literature review searched for studies with the keyword "child abuse" or "child neglected" or "covid-19 pandemic impact". Based on a search using these keywords, 8 articles were found from the data base.

\section{RESULT}

Table 1. Article review

\begin{tabular}{|c|c|c|c|c|c|}
\hline Author & Title & Journal & Sample & $\begin{array}{c}\text { Article } \\
\text { Type }\end{array}$ & Output \\
\hline $\begin{array}{l}\text { Maria Spinelli, } \\
\text { Francesca Lio- } \\
\text { netti, Massi- } \\
\text { miliano Pasto- } \\
\text { re, Mirco Fa- } \\
\text { solo, } 2020\end{array}$ & $\begin{array}{l}\text { Parents' stress and } \\
\text { children psycholo- } \\
\text { gical problems in } \\
\text { families facing the } \\
\text { COVID-19 out- } \\
\text { break in Italy }\end{array}$ & $\begin{array}{l}\text { Frontiers in } \\
\text { Psychology }\end{array}$ & $\begin{array}{l}854 \\
\text { Parents of } \\
2 \text { to } 14 \\
\text { years old } \\
\text { children }\end{array}$ & $\begin{array}{l}\text { Original } \\
\text { research } \\
\text { article }\end{array}$ & $\begin{array}{l}\text { The results of the } \\
\text { correlation values above } \\
.06 \text { were significant at } p< \\
\text {.05 tested by Pearson test. } \\
\text { Results showed that } \\
\text { overall there were no } \\
\text { relevant associations of } \\
\text { COVID-contact risk index } \\
\text { and Home environment } \\
\text { risk index with dyadic } \\
\text { parenting stress (PSI), } \\
\text { parent's individual stress } \\
\text { (DASS), and children's } \\
\text { psychological problems }\end{array}$ \\
\hline
\end{tabular}




\begin{tabular}{|c|c|c|c|c|c|}
\hline & & & & & (SDQ). \\
\hline $\begin{array}{lll}\text { Lee } & \text { et } & \text { al., } \\
2020 & & \end{array}$ & $\begin{array}{l}\text { Impact of COVID- } \\
19 \text { on the Mental } \\
\text { Health and Well- } \\
\text { being of Caregi- } \\
\text { vers and Families } \\
\text { of Autistic people }\end{array}$ & $\begin{array}{l}\text { The Cana- } \\
\text { dian Institu- } \\
\text { tes of Health } \\
\text { Research }\end{array}$ & 22 article & $\begin{array}{l}\text { A Rapid } \\
\text { Synthesis } \\
\text { Review }\end{array}$ & $\begin{array}{l}\text { Families who have chil- } \\
\text { dren with special needs } \\
\text { experience increased } \\
\text { stress due to internal and } \\
\text { external stressors due to } \\
\text { self-isolation during the } \\
\text { COVID-19 pandemic. } \\
\text { However, the existing lite- } \\
\text { rature does not explain the } \\
\text { level of stress experienced } \\
\text { by parents so that it dis- } \\
\text { rupts the quality of the re- } \\
\text { lationship between parents } \\
\text { and children. }\end{array}$ \\
\hline $\begin{array}{l}\text { Ginny Sprang, } \\
\mathrm{PhD} \text {, and Mi- } \\
\text { riam Silman, } \\
\text { MSW, } 2013\end{array}$ & $\begin{array}{l}\text { Posttraumatic } \\
\text { Stress Disorder in } \\
\text { Parents and Youth } \\
\text { After Health-Rela- } \\
\text { ted Disasters }\end{array}$ & \begin{tabular}{|l|}
\multicolumn{2}{|l|}{ Disaster } \\
Med Public \\
Health Pre- \\
paredness
\end{tabular} & $\begin{array}{l}398 \\
\text { parents }\end{array}$ & $\begin{array}{l}\text { Original } \\
\text { research } \\
\text { article }\end{array}$ & $\begin{array}{l}\text { Disease-containment mea- } \\
\text { sures such as quarantine } \\
\text { and isolation can be trau- } \\
\text { matizing to a significant } \\
\text { portion of children and } \\
\text { parents. Criteria for PTSD } \\
\text { was met in } 30 \% \text { of isola- } \\
\text { ted or quarantined children } \\
\text { based on parental reports, } \\
\text { and } 25 \% \text { of quarantined or } \\
\text { isolated parents (based on } \\
\text { self-reports). }\end{array}$ \\
\hline $\begin{array}{l}\text { Samantha M. } \\
\text { Brown, Jenalee } \\
\text { R. Doom, Ste- } \\
\text { phanie Lechu- } \\
\text { ga-Peña, Sarah } \\
\text { Enos Watamu- } \\
\text { ra, Tiffany } \\
\text { Koppels, } 2020\end{array}$ & $\begin{array}{lr}\text { Stress } & \text { and } \\
\text { Parenting } & \text { during } \\
\text { the } & \text { Global } \\
\text { COVID-19 } & \\
\text { Pandemic } & \end{array}$ & $\begin{array}{l}\text { Child Abuse } \\
\& \text { Neglect }\end{array}$ & 2060 & $\begin{array}{l}\text { Original } \\
\text { research } \\
\text { article }\end{array}$ & $\begin{array}{l}\text { The high stress and } \\
\text { depression felt by parents } \\
\text { and caregivers due to the } \\
\text { COVID-19 pandemic has } \\
\text { the potential to cause child } \\
\text { abuse and neglect. }\end{array}$ \\
\hline $\begin{array}{l}\text { Benjamin et al, } \\
2020\end{array}$ & $\begin{array}{l}\text { Adolescent psy- } \\
\text { chiatric disorders } \\
\text { during the CO- } \\
\text { VID-19 pandemic } \\
\text { and lockdown }\end{array}$ & $\begin{array}{l}\text { Psychiatry } \\
\text { Research }\end{array}$ & $\begin{array}{l}\text { Not } \\
\text { available }\end{array}$ & $\begin{array}{l}\text { Literature } \\
\text { review }\end{array}$ & $\begin{array}{l}\text { The COVID-19 pandemic } \\
\text { and lockdown have a ne- } \\
\text { gative impact on the men- } \\
\text { tal health of child and ado- } \\
\text { lescents. Adolescents' in- } \\
\text { dividual, familial, and so- } \\
\text { cial factors, related to ado- } \\
\text { lescent mental health. } \\
\text { Adolescents are often vul- } \\
\text { nerable and require careful } \\
\text { consideration by care- } \\
\text { givers and healthcare sys- } \\
\text { tem adaptations. }\end{array}$ \\
\hline Griffith, 2020 & $\begin{array}{l}\text { Parental Burnout } \\
\text { and Child Mal- }\end{array}$ & $\begin{array}{|lr|}\text { Journal } & \text { of } \\
\text { Family } & \text { Vio- } \\
\end{array}$ & $\begin{array}{l}\text { Not avai- } \\
\text { lable }\end{array}$ & $\begin{array}{l}\text { Literature } \\
\text { review }\end{array}$ & $\begin{array}{l}\text { Parents who scored higher } \\
\text { on measures of parental }\end{array}$ \\
\hline
\end{tabular}




\begin{tabular}{|c|c|c|c|c|c|}
\hline & $\begin{array}{l}\text { treatment During } \\
\text { the COVID-19 } \\
\text { Pandemic }\end{array}$ & lence & & & $\begin{array}{l}\text { burnout also scored higher } \\
\text { on measures of escape } \\
\text { and suicidal ideation, re- } \\
\text { ported greater levels of } \\
\text { conflict with their partners } \\
\text { and higher levels of part- } \\
\text { ner estrangement ideation, } \\
\text { and indicated that that } \\
\text { they engaged in higher } \\
\text { levels of child abuse and } \\
\text { neglect. }\end{array}$ \\
\hline $\begin{array}{l}\text { Martinkevich } \\
\text { et al, } 2020\end{array}$ & $\begin{array}{l}\text { Physical child } \\
\text { abuse demands in- } \\
\text { creased awareness } \\
\text { during health and } \\
\text { socioeconomic } \\
\text { crises like } \\
\text { COVID-19 }\end{array}$ & $\begin{array}{l}\text { Acta Ortho- } \\
\text { paedica }\end{array}$ & $\begin{array}{l}\text { Not avai- } \\
\text { lable }\end{array}$ & $\begin{array}{l}\text { Literature } \\
\text { review } \\
\text { with } \\
\text { expert } \\
\text { opinions }\end{array}$ & $\begin{array}{l}\text { Despite the increased risk } \\
\text { of NAI during the } \\
\text { current COVID- } 19 \text { crisis, } \\
\text { the number of reports sus- } \\
\text { pecting NAI decreased by } \\
42 \% \text { during the lockdown } \\
\text { of the Danish society. } \\
\text { Healthcare professionals } \\
\text { fled only } 17 \% \text { of all re- } \\
\text { ports of suspected child } \\
\text { abuse in } 2016 \text {. }\end{array}$ \\
\hline $\begin{array}{lr}\text { Mia } & \text { Roje } \\
\text { Đapić, } & \text { Gorda- } \\
\text { na } & \text { Buljan } \\
\text { Flander, } & \text { Kreši- } \\
\text { mir } & \text { Prijatelj, } \\
2020 & \end{array}$ & $\begin{array}{l}\text { Children Behind } \\
\text { Closed Doors Due } \\
\text { to COVID-19 } \\
\text { Isolaton: Abuse, } \\
\text { Neglect and Do- } \\
\text { mestc Violence }\end{array}$ & $\begin{array}{l}\text { Psychiatry } \\
\text { Research }\end{array}$ & $\begin{array}{l}24 \\
\text { articles }\end{array}$ & $\begin{array}{l}\text { Literature } \\
\text { review }\end{array}$ & $\begin{array}{l}\text { A review conducted on } 24 \\
\text { articles shows that since } \\
\text { the onset of the COVID- } \\
19 \text { pandemic, findings } \\
\text { have emerged about nega- } \\
\text { tive psychological im- } \\
\text { pacts, such as post-trau- } \\
\text { matic stress, boredom and } \\
\text { financial problems. Recent } \\
\text { research has also shown } \\
\text { that during the COVID-19 } \\
\text { pandemic there is a risk of } \\
\text { child abuse and neglect } \\
\text { (Đapić et al., 2020). }\end{array}$ \\
\hline
\end{tabular}

\section{DISCUSSION}

Childhood is a period where an individual begins to learn more about something from his environment. The closest environment for children is the family, where in the family there are parents, caregivers or other family members. Families are required to be able to provide proper care for children so that children are able to grow and develop according to their age stages. Factors that influence parental care can be influenced by internal factors or external factors. One of the external factors that influence care is environmental conditions or external stressors, such as in this article that the Covid-19 pandemic condition can affect all groups of individuals, including parents and children.

For some parents the Covid-19 pandemic and self-isolation policies from the government have an impact on the loss of jobs owned by parents, reduced income, and for some other parents who have jobs and have children who are still in school, these parents also have more burdens, because parents must be able to share the time between the time spent doing their job and the time spent 
engaging in their child's online learning. Even though for some other parents, this lockdown condition or self-isolation can increase the frequency of parents gathering with their families.

The various pressures that parents have during the Covid-19 pandemic can cause stress so that it has an impact on the care of parents or caregivers in caring for children. If parents are unable to adapt the stress experience, a maladaptive coping mechanism can be formed in the parents or caregivers. One of the consequences of the negative coping mechanisms is the release of negative emotions on other people and children, which is the risk group for receiving inappropriate treatment due to the exclusion of the parents' negative coping mechanisms, so that children are more vulnerable to get abuse, neglect, and violence from their parents or caregivers.

Therefore, it is important to measure the level of stress in parents or caregivers in order to obtain the level of stress on the parents or caregivers and the need to measure the level of vulnerability of children to maltreatment from parents or caregivers to prevent child abuse and neglect. In addition, parents are expected to be able to exercise emotional control and trying to create a positive coping mechanism in dealing with stress, so that parents are able to provide proper care to children during the Covid-19 pandemic and child abuse and neglect can be avoided or minimized.

\section{CONFLICTS OF INTEREST}

The author declares that they have no conflict of interest

\section{REFERENCES}

APA. (2020). Stress in the Time of COVID-19. American Psychological Association, (May), 20192021.

Benjamin, S., Lachal, J., Radjack, R., Carretier, E., Minassian, S., Benoit, L., \& Rose, M. (2020). Adolescent Psychiatric Disorders During the COVID-19 Pandemic and Lockdown. Psychiatry Research, 291(June), 113264. https://doi.org/10.1016/j.psychres.2020.113264

Brown, S. M., Doom, J. R., Lechuga-Peña, S., Watamura, S. E., \& Koppels, T. (2020). Stress and Parenting during the Global COVID-19 Pandemic. Child Abuse \& Neglect.

Cluver, L., Lachman, J. M., Sherr, L., Wessels, I., Krug, E., Rakotomalala, S., ... Mcdonald, K. (2020). Parenting in a Time of COVID-19. The Lancet, 2019(20), 30736. https://doi.org/10.1016/S0140-6736(20)30736-4

Đapić, M. R., Flander, G. B., \& Prijatelj, K. (2020). Children Behind Closed Doors Due to COVID-19 Isolation: Abuse, Neglect and Domestic Violence. Psychiatry Research, 181-192. https://doi.org/10.20471/dec.2020.56.02.06

Gelder, V. (2020). Family Violence and COVID-19: Increased Vulnerability and Reduced Options for Support. International Journal of Mental Health Nursing. https://doi.org/10.1111/inm.12735

Griffith, A. K. (2020). Parental Burnout and Child Maltreatment During the COVID-19 Pandemic. Journal of Family Violence.

IASC. (2020). Addressing Mental Health and COVID-19 Outbreak Addressing Mental Health and Psychosocial Aspects of COVID-19 Outbreak.

Lee, V., Ma, C. A., Tablon, P., Ba, M., Ahmad, F., Gorter, W., ... Lai, J. (2020). Impact of COVID-19 on the Mental Health and Wellbeing of Caregivers and Families of Autistic people.

Martinkevich, P., Larsen, L. L., Græsholt-knudsen, T., Hellfritzsch, M. B., Petersen, K. K., Møller-,

Spinelli, M., Lionetti, F., Pastore, M., Fasolo, M., \& Kingdom, U. (2020). Parents' Stress and Children Psychological Problems in Families Facing the COVID-19 Outbreak in Italy. Frontiers in Psychology, 11, 1713. https://doi.org/10.3389/fpsyg.2020.01713

Sprang, G., \& Silman, M. (2013). Posttraumatic Stress Disorder in Parents and Youth After HealthRelated Disasters, (p 9), 105-110. https://doi.org/10.1017/dmp.2013.22 